\title{
Doppler ultrasound contribution in vesico- peritoneal and vesico-cutaneous fistulas diagnosis: two case reports of a new sign
}

\author{
Amégninou Mawuko Yao Adigo ${ }^{1,2^{*}}$ (D), Kokou Adambounou ${ }^{1,3}$, Tete Edem Kouevi-Koko ${ }^{4}$, \\ Kpalma Duga Bakpatina-Batako ${ }^{1}$ and Komlanvi Adjénou ${ }^{1}$
}

\begin{abstract}
Background: Report cases of vesico-peritoneal and vesico-cutaneous fistulas suspected to Doppler ultrasound confirmed by CT scan/conventional cystography and successfully treated.

Case presentation: Two male patients of 35- and 36-year-old, without any medical past history, had presented anuria and absence of miction respectively after a road traffic accident and a piece of wood penetrating the left thigh. The physical examination revealed lower limbs hematoma and severe abdominal pain in the man of 35 years and a sutured wound of the left thigh of $4 \mathrm{~cm}$ with a bright liquid flowing from it with the characteristic smell of urine in the man of 36 years. A Doppler ultrasound was made. The Doppler had shown normal ureteral jets but with a third abnormal flux which went from interior to exterior of the urinary bladder for the first patient and from the bladder to the left inguinal cutaneous tissue for the second patient. The treatment was a Foley's catheter into the bladder with antibiotics in the two cases after excision and separate suture of the peritoneum and bladder during umbilical laparotomy in the first case. The suites were simples.

Conclusions: The diagnostic contribution of CT/conventional cystography is well known and undisputed, but for Doppler ultrasound, it is anecdotal like in these cases we report. Nevertheless, there is a need to evaluate the semiological value of Doppler ultrasound contribution on a greater sample.
\end{abstract}

Keywords: Vesico-peritoneal fistula, Vesico-cutaneous fistula, Doppler ultrasound, Case report, Africa

\section{Background}

A vesico-peritoneal fistula is an intraperitoneal bladder rupture with urine accumulation in the peritoneal cavity caused by leakage of urine from the bladder. It occurs when there is a sudden increase of intravesical pressure secondary to a blow to the pelvis or lower abdomen. This increased pressure results in rupture of the dome, the weakest and most mobile part of the bladder. Intraperitoneal bladder ruptures account for $38-40 \%$ of all bladder ruptures [1]. Vesico-cutaneous fistulas are rare,

\footnotetext{
* Correspondence: landry05@gmail.com

'Radiology Department of Campus Teaching Hospital, University of Lome, Lome, Togo

${ }^{2}$ Radiology Department of Be Hospital, University of Lome, Lome, Togo Full list of author information is available at the end of the article
}

and the traumatic origin by thigh penetrating wound is exceptional. Imaging plays a crucial role in the diagnosis of these affections [2]. If the diagnostic contribution of $\mathrm{CT} /$ conventional cystography is well known and undisputed [2-5], for the Doppler ultrasound, it is anecdotal. We report two cases of vesico-peritoneal and vesicocutaneous fistulas suspected to Doppler ultrasound, confirmed by CT scan/conventional cystography and successfully treated.

\section{Case presentation \\ Case 1}

A man of 35-year-old came to our surgical emergency department with a history of anuria evolving for $24 \mathrm{~h}$ and progressive abdominal distention, secondary to lower

\section{Springer Open}

(c) The Author(s). 2020 Open Access This article is licensed under a Creative Commons Attribution 4.0 International License, which permits use, sharing, adaptation, distribution and reproduction in any medium or format, as long as you give appropriate credit to the original author(s) and the source, provide a link to the Creative Commons licence, and indicate if changes were made. The images or other third party material in this article are included in the article's Creative Commons licence, unless indicated otherwise in a credit line to the material. If material is not included in the article's Creative Commons licence and your intended use is not permitted by statutory regulation or exceeds the permitted use, you will need to obtain permission directly from the copyright holder. To view a copy of this licence, visit http://creativecommons.org/licenses/by/4.0/. 
abdominal contusion caused by a traffic accident, since 4 days. Before his entrance in our hospital, a pelvic radiography and an abdominal ultrasound have been done. The pelvic radiography was normal, and the ultrasound concluded to a hemoperitoneum without any evidence of intraabdominal organ injury. He felt suprapubic pain. There were no clots in the urine. Before the trauma, the patient was fit and well with an unremarkable medical history (no history suggestive of liver, renal, or peritoneal disease). The Glasgow Coma Scale was 15/15. He was apyrexial and normotensive. The physical examination was normal except for lower limbs hematoma and abdominal deadness.

A second abdominal ultrasound was performed in our hospital and has shown an anechoic intraperitoneal free fluid collection (Fig. 1a) without liver, kidneys, spleen, pancreas, gall bladder, or blood vessel injury. There was also a parietal defect of the urinary bladder dome measuring a diameter of $10 \mathrm{~mm}$ (Fig. 1a). The Doppler has shown normal ureteral jets, but there was a third abnormal flux which went from interior to exterior of the urinary bladder (Fig. 1b). The CT scan has confirmed the bladder dome wall defect, the uroperitoneum, and the absence of intra-abdominal organ injury (Fig. 2a-c). The CT scan has not shown pelvic bone traumatic pathology. The diagnostics of vesico-peritoneal fistula with uroperitoneum (type 2 of the Société Internationale D'Urologie classification) have been retained.
A Foley's catheter was inserted into the bladder of the patient, and he was hospitalized in Urology Department. Under an umbilical laparotomy, the vesico-peritoneal fistula tract (Fig. 3) was excised, and the peritoneum and bladder were sutured separately. No intraoperative or postoperative complications were observed. The patient's urination returned to normal on day 6 post-operative. Ablation of the catheter was done. Since, the patient is doing well.

\section{Case 2}

It was a man of 36-year-old, without any known pathologic antecedents, being victim of a public road accident 4 days ago, by a piece of wood penetrating the left thigh. He was brought to the hospital where a bleeding wound has been noticed. He had benefit from an antitetanic sero-toxoid therapy, cleaning and suture of the wound, and an antalgic (injectable tramadol) and antibiotic treatment (oral ciprofloxacin and tinidazole). The bleeding cessation has motivated his exeat the next day. Two days after, he has consulted again for an absence of miction without feeling the desire to urinate evolving for 23 h. At the examination, it was noticed a wound of the left thigh already sutured of $4 \mathrm{~cm}$ of length with a bright liquid flowing from it (Fig. 4) with the characteristic smell of urine. A Doppler ultrasound performed had shown an edematous infiltration of the thigh soft tissues and the

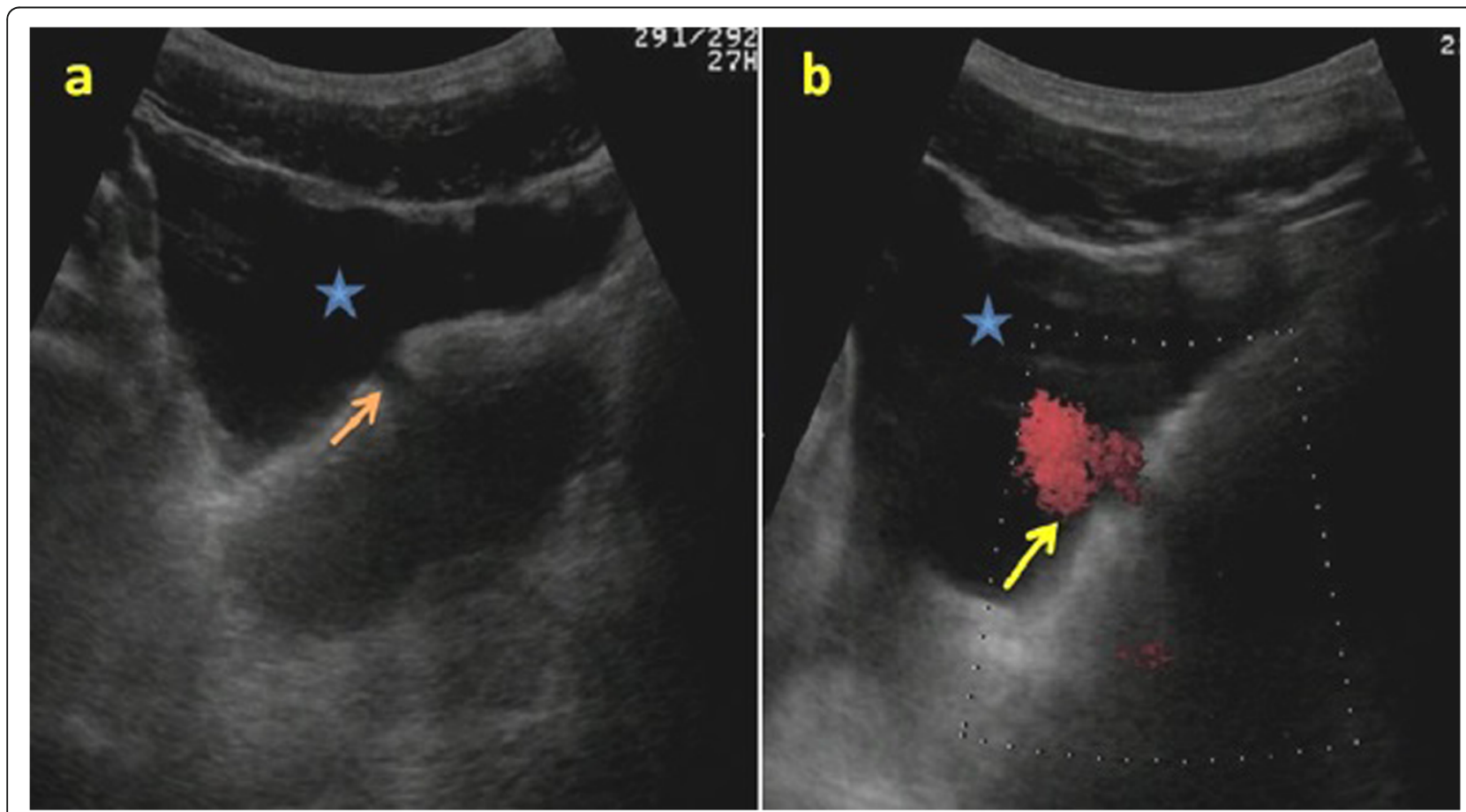

Fig. 1 Ultrasonographic images of intraperitoneal anechoic free fluid collection ( $\mathbf{a}$ and $\mathbf{b}$; blue star) with a rupture of the urinary bladder dome (a orange arrow). In $\mathbf{b}$, Doppler shows an abnormal signal, simulating a ureteral jet, but pointing from the inside to the outside of the bladder (yellow arrow) 


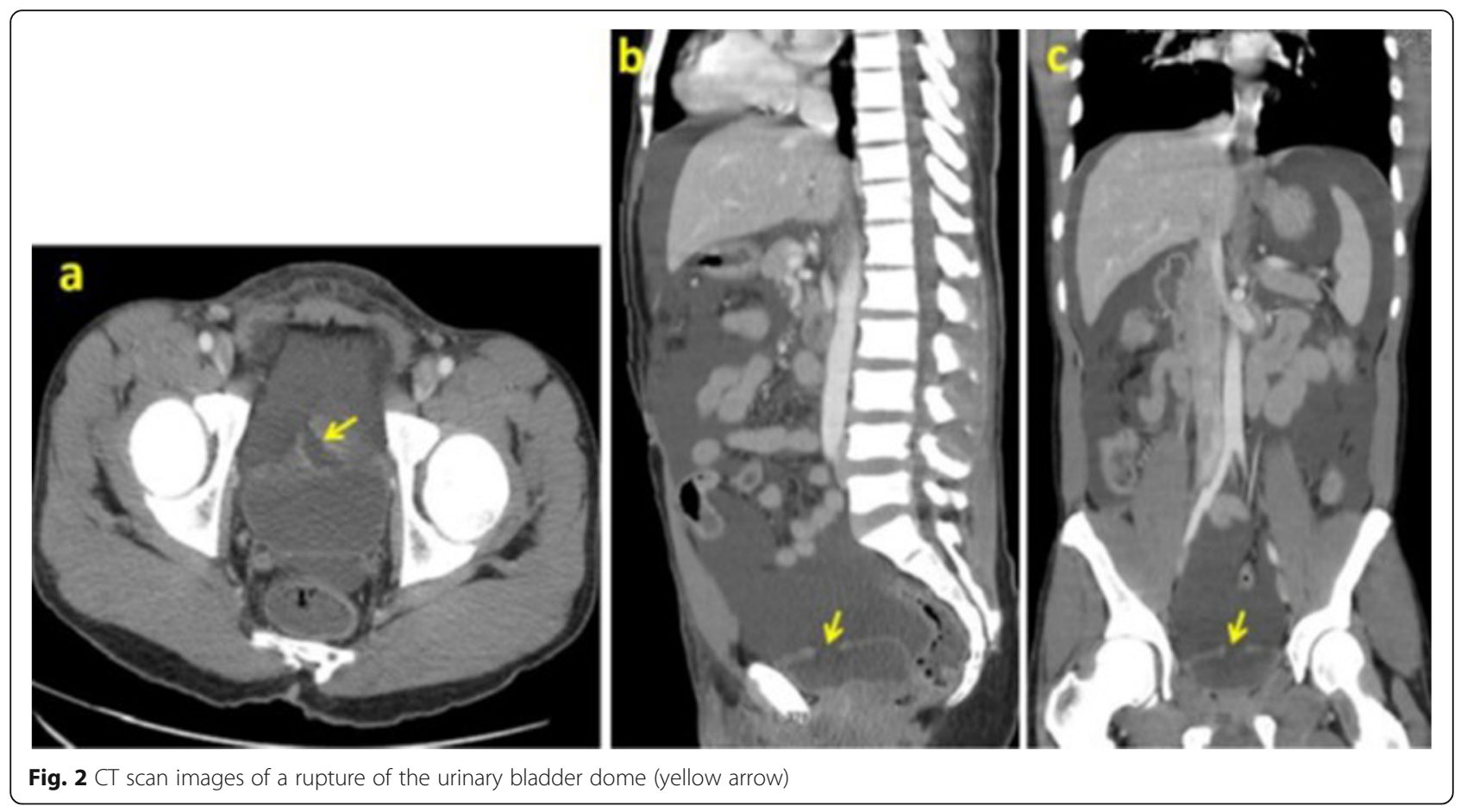

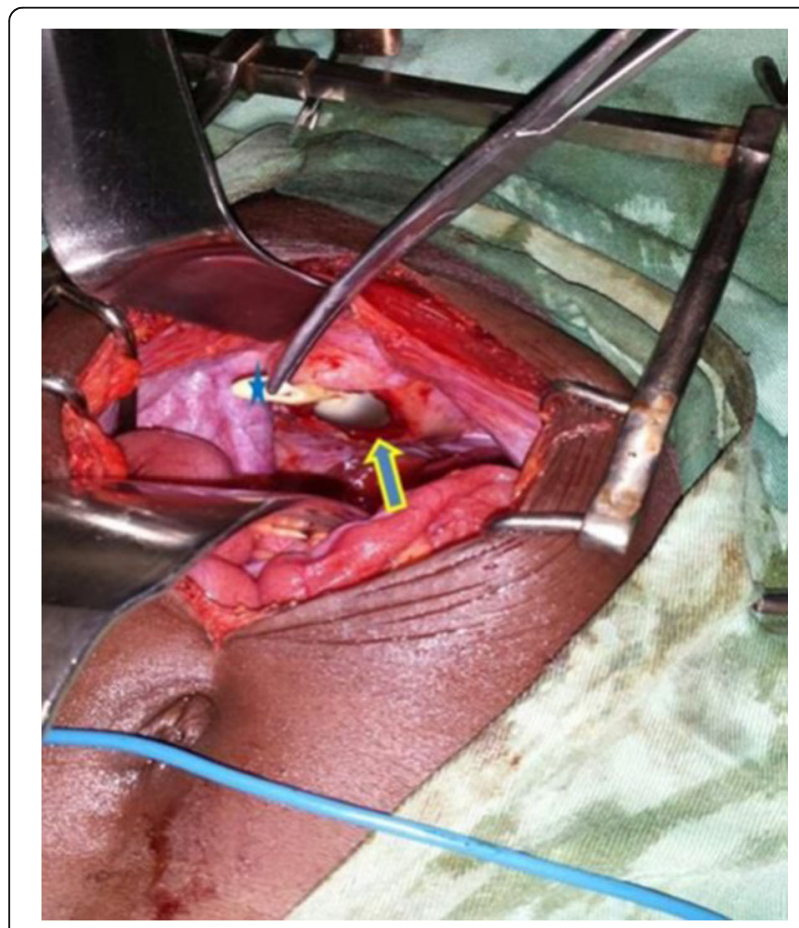

Fig. 3 Macroscopic image of a rupture of the urinary bladder dome (arrow). The blue star shows the end of Foley's catheter

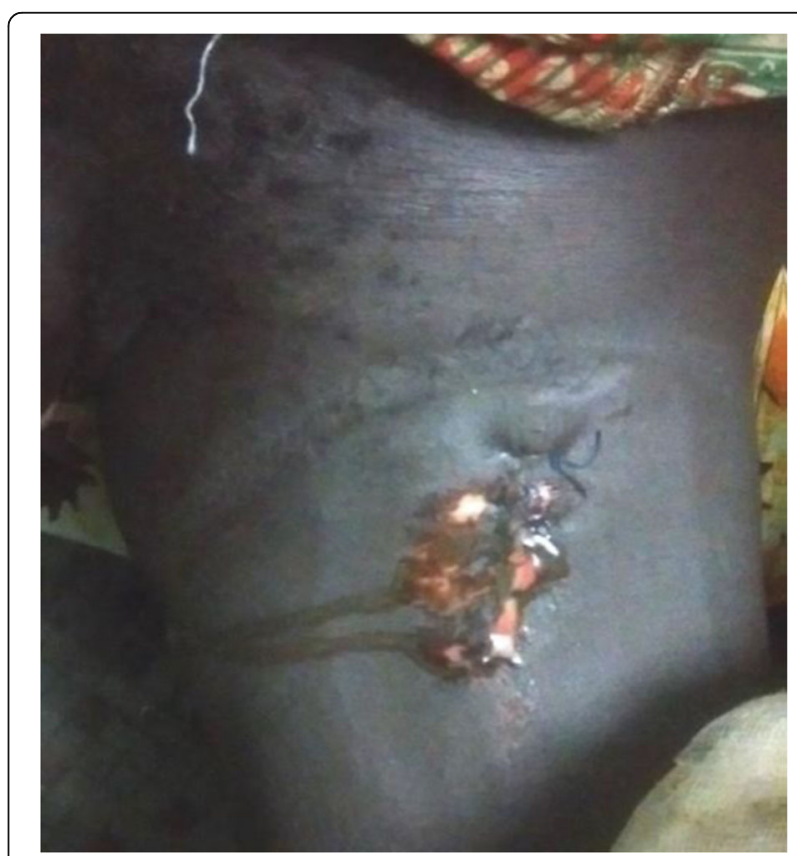

Fig. 4 Macroscopic image of a linear wound of the left thigh sutured, with a flow of bright liquid 
left hemi-hypogastrium (Fig. 5a), a low replete bladder (contrasting with the time elapsed since the last miction) associated to an abnormal Doppler signal, looking like the ureteral jet but going from the bladder to the left inguinal cutaneous tissue (Fig. 5b). The ureteral jets were normal. A retrograde uretro-cystography was made and has noticed a large fistula passage, $205 \mathrm{~mm}$ of length, making the bladder communicating with the left thigh cutaneous tissue (Fig. 6). The diagnosis of vesicocutaneous fistula (type 3 of the Société Internationale D'Urologie classification) by penetrating wound of the left thigh has been retained.

The treatment was based on setting a bladder indwelling catheter and the continuation of the antibiotic therapy and the local care. The evolution was favorable marked by the resumption of the desire of urinating on the 11th day motivating the removal of the vesical catheter on the 12th day with a miction re-becoming normal. The cicatrizing of the wound was obtained on the 19th day.

\section{Discussion}

The most frequent causes of bladder trauma are motor vehicle crashes (in which both seat belt compression of the bladder and ejection injuries may be responsible), falls, crush injuries, and blows to the lower abdomen [1]. Sixty percent to $90 \%$ (mean, $80 \%$ ) of patients with bladder injuries due to blunt trauma have associated pelvic fractures [1], and approximately $25 \%$ of intraperitoneal bladder ruptures occur in patients without a pelvic fracture [6]. In our case, there was no pelvic fracture associated to the urinary bladder intraperitoneal rupture. The patient has just lower abdomen contusion during traffic accident. The Société Internationale D’Urologie [1] classified bladder injury into four types, which do not take into account the length or extent of the bladder wall laceration: type 1 is bladder contusion; type 2 is intraperitoneal rupture; type 3 is extra peritoneal rupture; and type 4 is combined injury. The severity of urinary bladder injuries is graded from 1 to 5 (least to most severe) according to a classification system developed by the Organ Injury Scaling Committee of the American Association for the Surgery of Trauma (AAST) and is called the organ injury scale (OIS) [7]. We think that the first classification is more practical than the second for the radiologists. Our cases were classified in type 2 and type 3 of the Société Internationale D'Urologie classification.

The vesico-cutaneous fistulas are rare. Cases with a traumatic cause by penetrating wound of the gluteal region [8], calculous [9], iatrogenic [10], malformative [11], and secondary to an abdominal granulomatosis [12] were reported in the literature. Nevertheless, no traumatic etiology by penetrating wound of the thigh, and moreover by a piece of wood, have been reported, like in our case.

The role of imaging is essential in the diagnosis of vesico-peritoneal and vesico-cutaneous fistulas. CT cystography is equivalent to conventional cystography for detecting the presence or absence of blunt bladder injury. Cystogram and outpatient cystoscopy were imperative in the diagnosis [13]. CT cystography can be performed as an integral part of the CT screening undergone by many blunt trauma patients and, in the vast majority of these patients; it can alleviate the need for a separate conventional cystogram [3]. The role of $\mathrm{CT} /$ conventional cystography is undisputed, but for the a

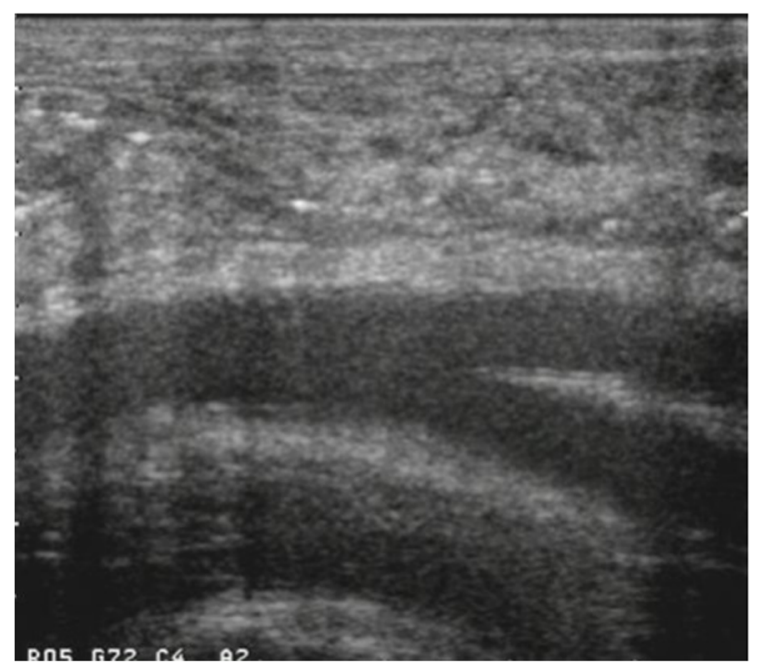

b

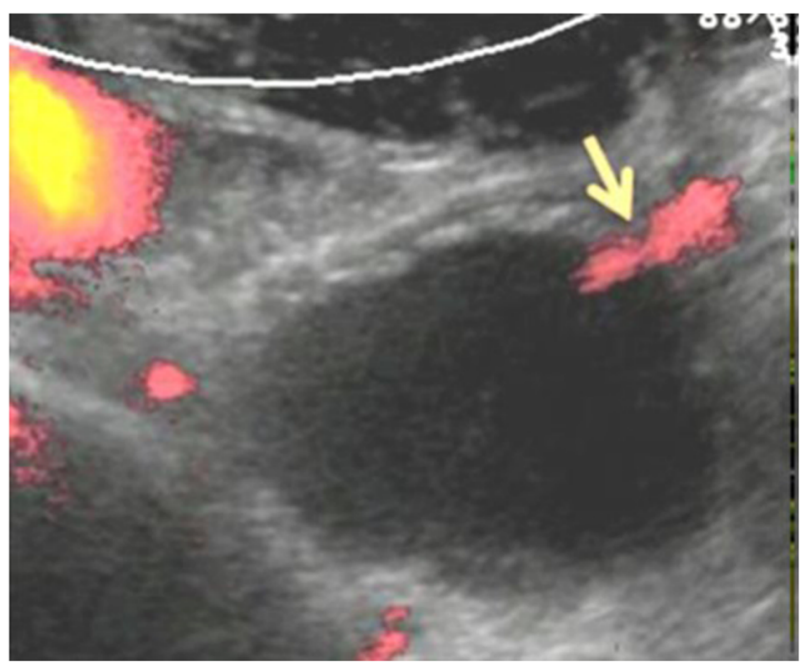

Fig. 5 a Ultrasonographic image of an edematous infiltration of the left inguinal soft tissues. $\mathbf{b}$ Low repleted bladder with an abnormal Doppler signal going from the bladder to the cutaneous tissue (arrow) 


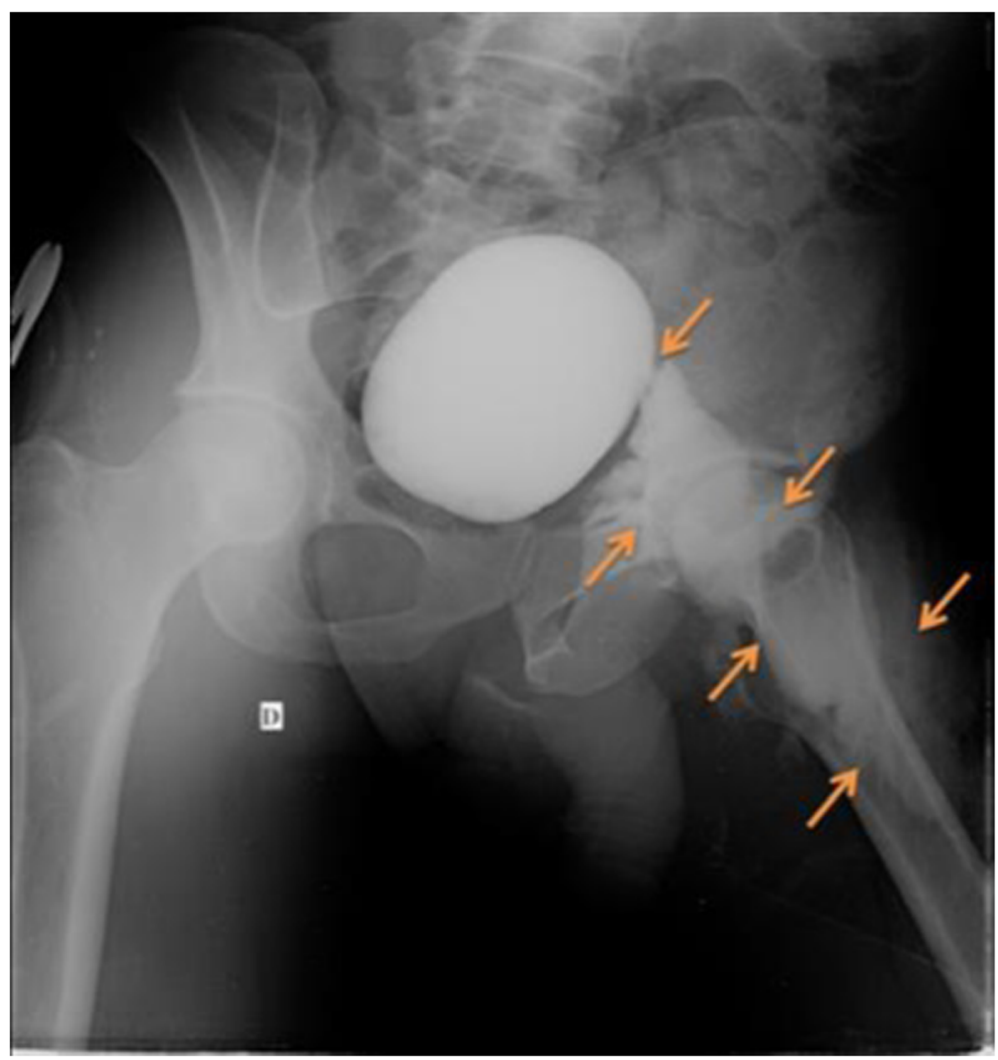

Fig. 6 Uretro-cystographic image of the vesico-cutaneous fistula passage (arrow) on the per voiding cliché

Doppler ultrasound, it is uncommon. They demonstrate a leakage of contrast into the peritoneal cavity from wall of the bladder. We report the two first cases of vesicoperitoneal and vesico-cutaneous fistulas suspected in Doppler ultrasound, and the wall bladder rupture was confirmed respectively by CT scan and conventional cystography. This diagnosis has been possible on the basis of a new sign (described here for the first time) called a sign of a third inverted ureteral jet: abnormal Doppler signal, simulating a ureteral jet, but pointing from the inside to the outside of the bladder with normal ureteral jets. This sign permit to exclude a partitioned intraperitoneal liquid fluid collection in the first case. This signal can be explained by a direct visualization of the movement of urine. It is important to understand that this flow visualization is not based on the Doppler effect, since the identification of the flow is not based on the measurement of a change in frequency or phase of the signal, but simply on the non-matching of the signal obtained at time $\mathrm{T} 1$ and time $\mathrm{T} 2$.

In the cases of vesico-cutaneous, ultrasound could show indirect signs evocative of the diagnosis such as: a low replete bladder, contrasting with the time elapsed since the last miction and the edematous infiltration of the cutaneous tissue.
We think that Doppler ultrasound can constitute a non-radiated and non-invasive imaging means in vesicoperitoneal and vesico-cutaneous fistulas diagnosis. This can be extended to all urinary bladder fistulas (vesico-vaginal, vesico-uterine, colovesical). Nevertheless, there is the need to evaluate the semiological value of this new sign on a greater sample. The detection of the fistulous tracts is not often, and the new signs mentioned is not accurate and not certitude diagnostic.

Surgical repair $[14,15]$ is the first treatment choice of intraperitoneal urinary bladder perforation, but catheter drainage alone can be applicable to minimal iatrogenic injuries [16]. Laparoscopic suture is an advantageous treatment of isolated intraperitoneal bladder rupture. Proactive management reduces infectious complications $[15,17,18]$. We have opted for a surgical care in our case and got a successful response.

The treatment of vesico-cutaneous is based on the setting of an indwelling bladder catheter with an antibiotherapy [8] like in our case. The rest of the treatment (pharmaceutical or surgical) will be function of the etiology [8-12]. 


\section{Conclusions}

Vesico-peritoneal fistula should be suspected in an anechoic intraperitoneal effusion, without intra-abdominal organ injury, in a trauma patient. Doppler ultrasound can enhance the diagnosis of vesico-cutaneous and vesico-peritoneal fistulas by the sign of the third inverted ureteral jet or Adigo's sign. Nevertheless, there is the need to evaluate the semiological value of this new sign on a greater sample.

\section{Abbreviations}

CT: Computed tomography; OIT: Organ Injury Scaling Committee;

AAST: American Association for the Surgery of Trauma

\section{Acknowledgements}

Not applicable.

\section{Patient's perspective}

The patients were very satisfied by the Doppler Ultrasound diagnosis and the surgery.

\section{Authors' contributions}

All authors have contributed to the conception and design of the manuscript; they have been involved in drafting and revising the manuscript. All authors read and approved the final manuscript.

\section{Funding}

The authors received no financial support for the research, authorship, and/ or publication of this article.

\section{Availability of data and materials}

The data used and/or analyzed during the current study are available from the corresponding author on reasonable request.

\section{Ethics approval and consent to participate}

Any experimental investigation with human beings at work was obtained with informed consent and complied with the ethical guidelines of the institution and the Helsinki Declaration of 1975 and its October 2000 revision. The study did not involve the use of animals. The manuscript has not been submitted to any other journal/site in part or in whole for consideration. It is solely submitted to this journal. The patient included in this study gave written informed consent to participate in this research.

\section{Consent for publication}

Written informed consent was obtained from the patient for publication of this case report and accompanying images.

\section{Competing interests}

The authors declare that they have no competing interests.

\section{Author details}

${ }^{1}$ Radiology Department of Campus Teaching Hospital, University of Lome, Lome, Togo. ${ }^{2}$ Radiology Department of Be Hospital, University of Lome, Lome, Togo. ${ }^{3}$ Biophysic Department of Campus Teaching Hospital, University of Lome, Lome, Togo. ${ }^{4}$ Surgical Department of Sylvanus Olympio Teaching Hospital, University of Lome, Lome, Togo.

Received: 8 May 2020 Accepted: 9 July 2020

Published online: 22 July 2020

\section{References}

1. Gomez RG, Ceballos L, Coburn M, Corriere JN Jr, Dixon CM et al (2004) Consensus statement on bladder injuries. BJU Int 94:27-32. https://doi.org/ 10.1111/j.1464-410X.2004.04896.x

2. Ramchandani P, Buckler PM (2009) Imaging of genitourinary trauma. AJR 192:1514-1523. https://doi.org/10.2214/AJR.09.2470

3. Quagliano PV, Delair SM, Malhotra AK (2006) Diagnosis of blunt bladder injury: a prospective comparative study of computed tomography cystography and conventional retrograde cystography. J Trauma 61(2):410422. https://doi.org/10.1097/01.ta.0000229940.36556.bf

4. Chan DP, Abujudeh HH, Cushing GL Jr, Novelline RA (2006) CT cystography with multiplanar reformation for suspected bladder rupture: experience in 234 cases. AJR Am J Roentgenol 187(5):1296-1302

5. Wirth GJ, Peter R, Poletti PA, Iselin CA (2010) Advances in the management of blunt traumatic bladder rupture: experience with 36 cases. BJU Int 106: 1344-1349. https://doi.org/10.1111/j.1464-410X.2010.09377.x

6. Sandler CM, Goldman SM, Kawashima A (1998) Lower urinary tract trauma. World J Urol 16:69-75

7. Moore EE, Cogbill TH, Jurkovich GJ, Mc Aninch JW, Champion HR (1992) Organ injury scaling. IIl: chest wall, abdominal vascular, ureter, bladder, and urethra. J Trauma 33:337-339

8. Jalloh M, Labou I, Diop A, Niang L, Trigui F, and al (2005) Fistule vésicocutanée par plaie pénétrante de la région glutéale par arme blanche associée à une lésion du nerf sciatique. A propos d'un cas. Afr J Urol 11 (3): 244-246.

9. Kobori Y, Shigehara K, Amano T, Takemae K (2007) Vesicocutaneous fistula caused by giant bladder calculus. Urol Res 35(3):161-163

10. Jaiswal P, Challacombe B, Dasgupta P (2005) Groin abscess: a vesicocutaneous fistula to the groin. A rare complication of open prostatectomy. Int J Clin Pract Suppl 147:113-114

11. Sarhan OM, Al-Ghanbar MS, Nakshabandi ZM (2013) Prune belly syndrome with urethral hypoplasia and vesico-cutaneous fistula: a case report and review of literature. Urology Annals 5(4):296-298.

12. Knausz J, Lipták J, Andrásovszky Z, Baranyay F (2010) Vesico-cutaneous fistula revealing abdominal wall malakoplakia accompanied by Boeck's sarcoidosis. Orv Hetil 151(6):220-3.

13. James R, Mahajan ST (2013) Concurrent vesicoperitoneal and vesicovaginal fistulae. Int Urogynecol J. 24(1):173-174. https://doi.org/10.1007/s00192-0111623-9

14. Ucer O, Yuksel MB, Temeltas G, Muezzinoglu T (2016) Vesicoperitoneal fistula: a rare late complication of laparoscopic removal of intrauterine device. Medical Science and Discovery 3(3):145-7. https://doi.org/10.17546/ msd.49832

15. Ooi WL, Sherwood BT, Stanley J, Baskaranathan S (2014) Vesico-peritoneal fistula: a rare cause of chronic abdominal pain. J Clin Urol. 7(2):121-2

16. Lin Y-C, Lin Y-C (2012) Intraperitoneal urinary bladder fistula caused by a Foley's catheter: a successfully conservative management. BMJ Case Reports https://doi.org/10.1136/bcr.01.2012.5630

17. Yahata T, Boshi E, Ino K, Nishi T (2019) Laparoscopic repair for vesicoperitoneal fistula with vesicouterine abscess. Gynecol and Minim Invasive Ther 8(4):172-5. https://doi.org/10.4103/gmit.gmit_82_18

18. Tatar B, Erdemoğlu E, Soyupek S, Yalçın Y, Erdemoğlu E (2016) Vesicocutaneus fistula after cesarean section-a curious complication: case report and review. Turk J Obstet Gynecol. 13(1):46-49.https://doi.org/10. 4274/tjod.71135.

\section{Publisher's Note}

Springer Nature remains neutral with regard to jurisdictional claims in published maps and institutional affiliations.

\section{Submit your manuscript to a SpringerOpen ${ }^{\circ}$ journal and benefit from:}

- Convenient online submission

- Rigorous peer review

- Open access: articles freely available online

- High visibility within the field

- Retaining the copyright to your article

Submit your next manuscript at $>$ springeropen.com 